\title{
Beliefs about School Learning during Adolescence: Their Contribution to Motivational Beliefs and School Achievement
}

\author{
Eleftheria N. Gonida ${ }^{1} \&$ Panayiota Metallidou ${ }^{1}$ \\ ${ }^{1}$ School of Psychology, Aristotle University of Thessaloniki, Greece \\ Correspondence: Eleftheria N. Gonida, School of Psychology, Aristotle University of Thessaloniki, Thessaloniki, \\ GR-541 24, Greece. Tel: 30-2310-99-7309. E-mail: gonida@psy.auth.gr
}

Received: May 17, 2015

Accepted: July 6, 2015

Online Published: September 28, 2015

doi:10.5539/jedp.v5n2p63

URL: http://dx.doi.org/10.5539/jedp.v5n2p63

\begin{abstract}
The aim of the present study was to examine the contribution of adolescents' beliefs about school learning to their achievement-related motivational beliefs and school achievement in mathematics. A Greek sample of 7,907 ninth $(\mathrm{N}=3,498)$ and tenth $(\mathrm{N}=4,409)$ graders of both genders were group examined using self-report questionnaires tapping their beliefs about school learning, personal achievement goals and self-efficacy in mathematics. Grade point average in mathematics was also used. Path analyses indicated both direct and indirect significant paths between the variables under examination. Overall, the findings of the present study support the importance of adopting a conception of school learning as a personal constructive process or as a force of personal empowerment and social change for the promotion of adaptive motivational patterns and increased achievement in mathematics. The results are discussed in light of current theory and their educational implications are pointed out.
\end{abstract}

Keywords: achievement goal orientations, adolescence, beliefs about school learning, school achievement, self-efficacy

\section{Introduction}

Understanding the underlying personal and/or situational factors behind students' engagement in the learning process and school outcomes remains a challenging topic among educational researchers. Students' beliefs about the nature and source of knowledge and the ways of knowing and learning have been acknowledged by a number of researchers as a critical component that sets the standards for this engagement either directly or indirectly by energizing other learning-related variables (e.g., Hofer, 2001; Hofer \& Pintrich, 1997; Muis \& Franco, 2009). Within this framework, the present study focuses on adolescents' beliefs about school learning as potential contributors to their achievement-related motivational beliefs such as goal orientations and self-efficacy, as well as to school achievement.

\subsection{Beliefs about Knowledge and Learning}

Different theoretical approaches have been adopted by the researchers studying the nature of knowledge and the ways of knowing and learning. In general, students' beliefs about knowledge and learning have been studied either within the tradition of epistemological thinking or the conceptions of learning tradition. In the epistemological tradition, many researchers have focused on the nature of knowledge and of knowing, that is beliefs about the certainty and the simplicity of knowledge and the source and the justification of knowing (e.g., Hofer \& Pintrich, 1997; Hofer, 2001), while others have included the beliefs about learning (i.e., speed of learning, ability to learn) as a particular set of epistemological beliefs (e.g., Schommer, 1990; Schommer-Aikins, 2002). They range at a continuum from more naive (i.e., knowledge is absolute and stable, transmitted by external authorities, a simple accumulation of facts or organized in isolated bits of information) to more sophisticated beliefs (i.e., knowledge is evolving, personally constructed, judged in contexts, and organized in networks of interrelated concepts) (e.g., Hofer \& Pintrich, 1997; Schommer, 1990; Schommer-Aikins, 2002).

A separate, although related, theoretical tradition that was initiated by Säljö (1979) and continued by other researchers (e.g., Marton, Dall'Alba, \& Beaty, 1993; Purdie \& Hattie, 2002) has been focused on how students' (mainly college ones) conceptualize learning. Qualitatively different conceptions of learning were identified (see 
Marton et al., 1993), which refer either to the content aspects of learning (what is learned) or to the process aspects (how someone learns). Namely, learning has been found to be conceptualized as: (a) a means of increasing one's knowledge, (b) a process of memorizing and reproducing knowledge or facts, (c) a process of abstracting the meaning and understanding, (d) a means of personal change, and (e) as a lifelong process or as a "duty" (Tynjälä, 1997). As in the case of sophisticated beliefs about knowledge and learning, a qualitative, constructivist conception of learning as a continuous lifelong process as compared to a more quantitative, reproductive conception has been associated to more adaptive learning patterns including cognitive, motivational and behavioral ones (e.g., Chan \& Sachs, 2001; Law, Chan, \& Sachs, 2008; Peterson, Brown, \& Irving, 2010).

\subsection{Beliefs about Knowledge and Learning: Associations with Achievement Goal Orientations, Self-Efficacy and Achievement}

The contribution of beliefs about knowledge and learning in academic engagement and learning outcomes has been widely acknowledged in the literature. Associations with cognitive as well as with motivational processes have been established both with college students and with elementary and secondary school students (e.g., Chen \& Pajares, 2010; DeBacker \& Crowson, 2006; Hofer \& Pintrich, 1997; Muis, 2008; Muis \& Duffy, 2014; Schommer, Calvert, Galigrietti, \& Bajaj, 1997; Schommer-Aikins, Duell, \& Hutter, 2005; Tsai et al., 2011). Within the epistemological tradition, past research has confirmed the predictive value of epistemological beliefs for personal achievement goals (e.g., Bråten \& Strømsø, 2004; Chen \& Pajares, 2010; DeBacker \& Crowson, 2006; Phan, 2009), self-efficacy (e.g., Chen \& Pajares, 2010; Tsai, Ho, Liang, \& Lin, 2011), school achievement (e.g., Schommer et al., 1997; Schommer-Aikins et al., 2005), and various aspects of self-regulated learning (e.g., Bråten \& Strømsø, 2005; Muis \& Franco, 2009). In general, the more sophisticated beliefs the person holds about the nature and process of knowledge and learning (i.e., complex, evolving and personally constructed), as opposed to more naïve beliefs (i.e., simple, stable and authority given), the more adaptive the learning patterns are (see also Schommer, 1994; Schommer-Aikins, 2002).

Personal achievement goal orientations represent the reasons for engaging in achievement-related behaviors and investing time and effort (for reviews, see Elliot, 2005; Midgley, 2002). According to the trichotomous framework, three goal orientations have been identified: mastery, performance-approach, and performance-avoidance (Elliot \& Harackiewitz, 1996; Middleton \& Midgley, 1997). A mastery orientation refers to a focus on understanding, skill acquisition, task mastery, and development of personal competence. A performance-approach orientation is focused on demonstrating higher competence as compared to others and gaining favorable judgments including school grades, whereas a performance-avoidance orientation is focused on avoiding the demonstration of lack of competence and unfavorable judgments. Research has established that mastery goals are consistently associated with adaptive patterns of learning, such as the use of deep cognitive strategies, intrinsic motivation, and persistence in the face of obstacles, while performance-avoidance goals with maladaptive ones, such as the use of surface strategies, low interest and intrinsic motivation, and low academic achievement. The evidence, however, about the performance-approach goals has not been very consistent, since they have been found to relate either to positive (e.g., high achievement and self-efficacy beliefs) or negative (e.g., test anxiety and avoidance of help seeking) outcomes or not related to any outcomes at all (Church, Elliot, \& Gable, 2001; Gonida, Kiosseoglou, \& Voulala, 2007; Gonida, Voulala, \& Kiosseoglou, 2009; Middleton \& Midgley, 1997; Tuominen-Soini, Salmela-Aro, \& Niemivirta, 2012).

There is a growing research interest in the pattern of relations between personal goal orientations and beliefs about learning, mainly within the epistemological tradition. A consistent direct predictive path from epistemological beliefs to personal achievement goal orientations has been confirmed with naïve epistemological beliefs to predict mastery orientation negatively and performance orientation positively (especially the performance-avoidance goal orientation). Bråten and Strømsø (2004) indicated that performance-approach and performance-avoidance goal orientations were more likely to be adopted by university students with naïve beliefs such as that learning occurs quickly, whereas mastery goals were less likely to be adopted by the same students as well as by those believed in stable and given knowledge. DeBacker and Crowson (2006) in their study with university students indicated a negative predictive path from naïve epistemological beliefs to mastery goals and a positive path to performance goals (both approach and avoidance). Phan (2009) confirmed the significant contribution of epistemological beliefs to the adoption of personal achievement goals in a sample of Asian students. He found, however, a direct positive contribution of sophisticated epistemological beliefs to both mastery and performance goals. This evidence might emphasize the importance of taking into consideration the potential cultural influences in the domain of epistemological beliefs, the way school success is defined in different contexts, as well as students' multiple goals in achievement settings. 
The abovementioned studies have been conducted mostly with university or college students and only very few studies have examined elementary, middle or high school students. Chen and Pajares (2010) in their influential study with sixth graders indicated that sophisticated beliefs about science (e.g., scientific claims need justification) were directly positively associated with task (mastery) goal orientation, whereas more naïve epistemological beliefs about science (e.g., science knowledge comes from external authorities and there is absolute scientific truth) beliefs directly predicted performance achievement goal orientations. Metallidou, Megari and Konstantinopoulou (2010) expanded previous evidence from university students to a population of Greek secondary school students (8th to 11th grade). Naïve epistemological beliefs about the structure and stability of knowledge as well as about the speed of learning were found to predict the adoption of mastery goals negatively, while naïve beliefs about the ability to learn were found to predict performance goals (both approach and avoidance) positively.

Self-efficacy refers to one's beliefs that she/he is capable of organizing and performing successfully a specific task (Bandura, 1986). Academic self-efficacy is considered as a key motivational variable, since it has been consistently associated to deep cognitive and/or metacognitive strategies use (e.g., Greene, Miller, Crowson, Duke, \& Akey, 2004) and has been indicated as an important predictor of students' learning and achievement outcomes in various domains (e.g., Gonida \& Leondari, 2011), even a stronger predictor as compared to other motives, such as task value or test anxiety (Metallidou \& Vlachou, 2007). The relationship of self-efficacy beliefs with achievement goal orientations has been consistently supported in the literature, with mastery goals to have a positive effect on self-efficacy beliefs (Friedel, Cortina, Turner, \& Midgley, 2007; Middleton \& Midgley, 1997), while performance-avoidance goals to have a negative effect on the same variable (e.g., Middleton \& Midgley, 1997). In regard to their potential associations with beliefs about knowledge and learning, Chen and Pajares (2010) indicated that 6th graders' epistemological beliefs about science predicted science grade self-efficacy and achievement directly, as well as indirectly via students' science goal orientations. Recently, Tsai and his associates (2011) indicated that secondary school students' high-level conceptions of learning science (that is, increase of knowledge, applying and understanding) positively predicted students' self-efficacy beliefs of learning science, while the opposite was true in the case of lower-level conceptions of learning science (that is, memorizing, testing, calculating and practicing).

\subsection{The Rationale of the Present Study}

As has already been mentioned, the underlying assumption in the literature up to now is that the beliefs about knowledge and learning students adopt are associated to cognitive, motivational and learning outcomes. These beliefs have been approached either as general, domain-free or as domain-specific, usually associated to specific school subjects such as science. Recently, Muis, Bendixen and Haerle (2006) introduced the notion of "academic epistemic beliefs" which develop in the educational context and primarily during the academic years. In their three level model of epistemology, they distinguish three types of socially constructed and context bound epistemic beliefs, namely general, academic and domain-specific. The academic epistemic beliefs constitute the middle level of the model and are considered as amalgamations of the "general epistemic beliefs" which develop in non-academic contexts such as home, work, and peer settings and of the "domain-specific beliefs" which develop in specific instructional contexts that students meet in their school career (e.g., beliefs about learning science, see Chen \& Pajares, 2010; Tsai et al., 2011, or beliefs about writing, see Sandres-Reio, Alexander, Reio, $\&$ Newman, 2014).

The present study focuses on adolescents' beliefs about school learning, that is, academic epistemic beliefs that develop within school and refer to learning which is taught at school. The emphasis on students' beliefs about school learning (instead of learning or knowledge in general or of domain-specific epistemic beliefs) is of particular importance within the educational context. In addition to domain-specific beliefs for each school subject, students also tend to conceptualize school learning within their school context and independently of the particular subjects. Especially for adolescents, school represents a major, if not the major, context of learning and source of knowledge, which is perceived as mostly determined by others in terms of the curriculum and the instructional practices. Consequently, adolescents' learning patterns at school, including achievement in specific subjects, are likely to be associated with their beliefs about school learning, as well.

Similarly with this rationale and based on the epistemological beliefs literature as well as on the conceptions of learning tradition, Mansell, Greene and DeBacker (2004) developed a self-report measure named "Beliefs about School Learning Questionnaire" (BSLQ) to capture how students conceptualize school/academic learning. These beliefs are approached as domain-free in terms of school subjects that rather represent the type of learning which 
is associated to school in general as a source of learning and knowledge. Specifically, the authors introduce three different conceptual dimensions of school learning: (a) school knowledge and learning as a means of subjugation of personal opinion to the opinions or actions of authorities, (b) school learning as a means of personal empowerment and social change, and (c) school learning as an active process of personal construction of knowledge. The main advantages of the particular measure include, first, its focus on specific beliefs about school learning and not learning and knowing in general as a mental process, and, second, the consideration of both the traditional, namely the constructivist vs the reproductive view of learning, and the new conceptions of learning as a socially and personally derived need. Moreover, this instrument is an attempt to combine the two related, although separate, theoretical traditions in the area, the epistemological and the conceptions of learning tradition. The students report not only their beliefs about the nature and the source of school knowledge, but their beliefs about the school learning as a process, as well.

Thus, the objective of the present study was to explore the potential contribution of adolescents' beliefs about school learning to achievement-related motivational beliefs such as goal orientations and self-efficacy beliefs, as well as to school achievement. Achievement goal orientations were approached independently of school subjects, whereas mathematics was used for self-efficacy beliefs and achievement. As Bandura (1997) notably argued, self-efficacy beliefs should be measured within a given domain and not as a global measure. Specific scales within a particular school subject should be used in order to be able to predict students' outcomes in the same subject more accurately (Pajares \& Schunk, 2001). Mathematics was chosen as a highly valued curriculum subject, mainly due to its high utility for future educational and career choices and success.

The evidence on the interrelationships of epistemic beliefs with motivation and performance comes mostly from studies with university or college students and only few recent studies have attempted to extend their scope in school children and adolescents (e.g., Cano, 2005; Chen \& Pajares, 2010; Tsai et al., 2011). Further, most of the studies have examined the direct effects of beliefs about knowledge and learning on study or learning approaches and only few examined their direct effects on achievement-related motivational beliefs and academic performance (e.g., Cano \& Cardelle-Elawar, 2004; Chen \& Pajares, 2010; Peterson et al., 2010; Tsai et al., 2011). Thus, the present study aims to offer additional evidence for the direct and indirect associations among the variables under examination in regard to adolescence, a developmental period with important future-related academic challenges. The empirical importance of studying the contribution of adolescent students' beliefs about school learning to their motivation and achievement also stems from the declining trends in the value adolescents assign on learning and schooling as well as in their achievement-related motivational beliefs such as mastery goal orientations and self-efficacy beliefs, declining trends which are usually related to both puberty and school context (see, for example, Eccles \& Midgley, 1989; Author et al., 2007; Pajares \& Valiante, 2002; Urdan \& Midgley, 2003). Further, epistemological beliefs undergo a significant change during adolescence becoming more complex and less naive and simplistic (Cano, 2005).

According to the relevant empirical evidence, it was hypothesized that, on the one hand, beliefs about school learning as a means of personal empowerment and as a constructive process would have direct positive effects on mastery and performance-approach orientations, self-efficacy beliefs and school grades, and direct negative effects on performance-avoidance orientation (Hypothesis 1a). On the other hand, beliefs about school learning as subjugation were expected to directly predict the above variables in the opposite way (Hypothesis 1b). Mastery and performance-approach orientations were hypothesized as direct positive predictors of self-efficacy beliefs, while performance-avoidance orientation as negative predictor (Hypothesis 2a). It was also hypothesized that self-efficacy beliefs in mathematics would have a direct positive influence on the respective school achievement (Hypothesis 2b). As regards the indirect paths, beliefs about school learning were expected to predict achievement via goal orientations and self-efficacy beliefs (Hypothesis 3 ).

\section{Method}

\subsection{Participants}

The present study was part of a broader research project demanding sample representativeness. Thus, a representative sample of 7907 Greek ninth $(\mathrm{N}=3498)$ and tenth $(\mathrm{N}=4409)$ graders of both genders participated in the study. Data regarding the population residential distribution all over the country and the student population attending 9th and 10th grade (15-16 years of age) as distributed in the country were provided by the Hellenic Statistical Authority, whereas the list of the schools in all regions was provided by the Ministry of Education. A multi-stage stratification procedure was applied for data collection in order for all geographic regions of the country, urban (27\%) and rural areas (73\%) and both genders ( $49 \%$ boys and $51 \%$ girls) to be represented in the 
sample. The final selection of the participating schools was achieved in collaboration with the local school authorities in order any particular characteristics of each region to be taken into account. In regard to parental education, $22 \%$ of the students' fathers and $22 \%$ of their mothers had a university degree, $56 \%$ of their fathers and $55 \%$ of mothers had finished senior high school, and $22 \%$ of the students' fathers and $23 \%$ of their mothers had only finished elementary school.

\subsection{Measures}

Self-report questionnaires were used to measure all the variables under examination except achievement. Students were asked to rate their degree of agreement with each item on a 5-point Likert type scale (1: strongly disagree to 5: strongly agree). Translation and back translation was applied for the questionnaire measuring beliefs about school learning, whereas the achievement goal orientations and self-efficacy measures had been used successfully in previous studies in Greece.

\subsubsection{Beliefs about School Learning}

As referred earlier, the questionnaire measuring beliefs about school learning was developed by Mansell, Greene, and DeBacker (2004). It comprised three different conceptual dimensions of school learning which were confirmed in the Greek sample: (a) school learning as a means of personal empowerment and social change (7 items, e.g., "If I want to have the power to change society, I need to learn as much as possible"), (b) school learning as a tool of authority aiming to subjugation of personal opinion and avoidance of social change (8 items, e.g., "The type of knowledge that you learn in school is only useful if you agree with mainstream authorities"), and (c) school learning as an active process of personal construction of knowledge (8 items, "When I learn in school, I am helping to create the knowledge that I am learning"). Principal component analysis with varimax rotation applied on the data. Eigen values, explained variance by each factor, and Cronbach reliability indices for all constructs are given in Table 1.

\subsubsection{Personal Achievement Goal Orientations}

The Greek version of the questionnaire developed by Midgley and her associates (Midgley et al., 1998) was used (adapted by Gonida et al., 2007). According to the trichotomous theoretical framework for student achievement goal orientations, the scale consisted of three subscales measuring mastery orientation (6 items, e.g., "An important reason why I do my class work is because I like to learn new things"), performance-approach orientation (6 items, e.g., "Doing better than other students in class is important to me") and performance-avoidance orientation ( 5 items in the Greek version instead of 6 items, e.g., "One of my main goals is to avoid looking like I can't do my work"). As in previous empirical studies in Greece (e.g., Gonida et al., 2007, 2009; Metallidou et al., 2010), principal component analysis with varimax rotation confirmed the theoretical structure of the questionnaire (see Table 1).

\subsubsection{Self-Efficacy Beliefs}

A slightly modified version of the Pintrich and De Groot (1990) scale was used (adapted by Gonida \& Leondari, 2011). Students were asked to respond to nine items measuring their expectancies to do well in mathematics as well as their level of confidence in this subject (e.g., "I expect to do very well in mathematics this year"). As expected, principal component analysis with varimax rotation yielded a single factor (see Table 1).

Table 1. Eigen values, explained variance and $\alpha$ values for the study variables

\begin{tabular}{lccc}
\hline Scales & Eigenvalue & $\begin{array}{c}\text { \% of explained } \\
\text { variance }\end{array}$ & Cronbach $\alpha$ \\
\hline School learning as personal empowerment and social change & 5.31 & 13.65 & .78 \\
School learning as subjugation & 2.73 & 13.61 & .75 \\
School learning as a constructive individual process & 1.08 & 12.39 & .73 \\
Mastery goal orientation & 5.19 & 19.40 & .82 \\
Performance-approach orientation & 2.43 & 19.19 & .83 \\
Performance-avoidance orientation & 1.08 & 12.60 & .66 \\
Self-efficacy (Math) & 5.71 & 63.47 & .93 \\
\hline
\end{tabular}




\subsubsection{School Achievement in Mathematics}

The grade in mathematics from the previous school term was used (0-20 scale).

\subsubsection{Demographic Data}

Students were asked to provide their age, gender, school, grade level, and their parents' educational level.

\subsection{Procedure}

All measures were group administered in paper and pencil form by trained research assistants in early spring. Parental permission as well as permission by the Hellenic Institute of Education and the schools' administration was provided in advance. Students participated on a voluntary basis after being informed about the purpose of the study and assured for the confidentiality of their responses.

\section{Results}

\subsection{Preliminary Analyses, Descriptive Statistics, and Intercorrelations}

Prior to examining the specific objectives of the study, gender and parental education differences regarding the variables of the study were examined. Due to the large sample size, partial eta squared $\left(\eta^{2}\right)$ was used to determine significance (Cohen, 1988). Although most $p$ values were significant for all three independent variables (gender, mother education, father education), almost all the effect sizes were very low (up to $\eta^{2}=.020$ ) indicating non-significance, in general. Therefore, none of the above demographic variables were used in the subsequent analyses.

To determine whether parametric analyses could be applied on the data, measures of skewness and kurtosis were applied. All the values of skewness and kurtosis were below 2 and considered to be normally distributed (see Kline, 2011). Means, standard deviations, skewness and kurtosis values are presented in Table 2. The intercorrelations among all the examined variables, except one, were significant at $p<.001$, ranging from $r=.07$ to $r=.64$ (see Table 3). The correlation between performance-approach goals and achievement was the only non-significant one $(r=.02, p>.05)$.

Table 2. Descriptive statistics

\begin{tabular}{lcccc}
\hline Variables & Mean & SD & Skewness & Kurtosis \\
\hline School learning as a constructive individual process & 3.38 & .64 & -.270 & .588 \\
School learning as subjugation & 2.76 & .72 & .207 & .004 \\
School learning as a means of personal empowerment and & 3.44 & .80 & -.266 & .060 \\
social change & & & & \\
Self-efficacy (Math) & 3.10 & 1.00 & -.138 & -.702 \\
Mastery goal orientation & 3.33 & .88 & -.292 & -.363 \\
Performance-approach orientation & 3.00 & .97 & -.082 & -.652 \\
Performance- avoidance orientation & 2.76 & .86 & .130 & -.404 \\
Achievement in Mathematics & 14.63 & 3.24 & -.099 & -.986 \\
\hline
\end{tabular}

Table 3. Bivariate correlations of the study variables

\begin{tabular}{lccccccc}
\hline \multicolumn{1}{c}{ Variables } & 1 & 2 & 3 & 4 & 5 & 6 & 7 \\
\hline 1. BSL as constructive individual process & & & & & & & \\
2. BSL as subjugation & $.32^{* *}$ & & & & & \\
3. BSL as personal empowerment & $.64^{* *}$ & $.16^{* *}$ & - & & & & \\
$\quad$ social change & & & & & & & \\
4. Mastery Goals & $.43^{* *}$ & $.11^{* *}$ & $.44^{* *}$ & & & & \\
5.Performance-approach Goals & $.26^{* *}$ & $.26^{* *}$ & $.27^{* *}$ & $.35^{* *}$ & & & \\
6.Performance-avoidance Goals & $.19^{* *}$ & $.32^{* *}$ & $.17^{* *}$ & $.24^{* *}$ & $.58^{* *}$ & & \\
\hline
\end{tabular}




\begin{tabular}{llllllll}
\hline 7. Self-efficacy beliefs in Maths & $.30 * *$ & $.11 * *$ & $.32 * *$ & $.30 * *$ & $.23 * *$ & $.07 * *$ \\
8. Achievement in Mathematics & $.12 * *$ & $-.19^{* *}$ & $.20^{* *}$ & $.12 * *$ & .02 & $-.11 *$ & $53 * *$ \\
\hline
\end{tabular}

Note. ${ }^{* * p}<.001,{ }^{*} p<.05$

\subsection{Direct and Indirect Effects on Achievement}

In order to explore the direct and indirect effects of beliefs about school learning on motivation and achievement, path analyses were applied on the data using Mplus 5 (Muthén \& Muthén, 2007). Multiple measures of goodness-of-fit were used. Due to the large sample of the study, model fit statistics that are more resistant to the impact of large samples were preferred such as the Standardized Root Mean Square Residual (SRMR) and the Root Mean Square Error of Approximation (RMSEA) (Fan \& Sivo, 2007; Hu \& Bentler, 1999). The ordering of the variables followed previous empirical evidence and theoretical assumptions as stated earlier in the introduction (Kline, 2010). Thus, direct paths were drawn from BSL to goal orientations, self-efficacy beliefs, and achievement. Further, direct paths were drawn from goal orientations to self-efficacy beliefs and from self-efficacy beliefs to achievement. Indirect paths were also tested. Path analysis indicated that the hypothesized model had a good fit to the data. Due to the large size of the sample, the strict significance criterion of $p<.001$ was set for the $\mathrm{z}$ values of the coefficients. The indices of the model were: $\chi^{2}(8)=306.25, p<.001$, CFI $=.971$, RMSEA $=.07$, SRMR $=.03$. Four non-significant paths were removed. Figure 1 presents standardized direct path coefficients.

In addition to the direct paths which are shown in Figure 1, achievement in mathematics was explained indirectly by the beliefs about school learning as personal empowerment $(\beta=.11, p<.01)$ as well as by the beliefs as a constructive process $(\beta=.09, p<.01)$ via goal orientations and self-efficacy. Goal orientations had only significant indirect effects on math achievement $(\beta=.08, p<.001$ for mastery goal orientation and $\beta=.09, p$ $<.001$ for performance-approach goal) via their direct path to self-efficacy. The total percentage of achievement explained by the above direct and indirect effects was $34 \%$.

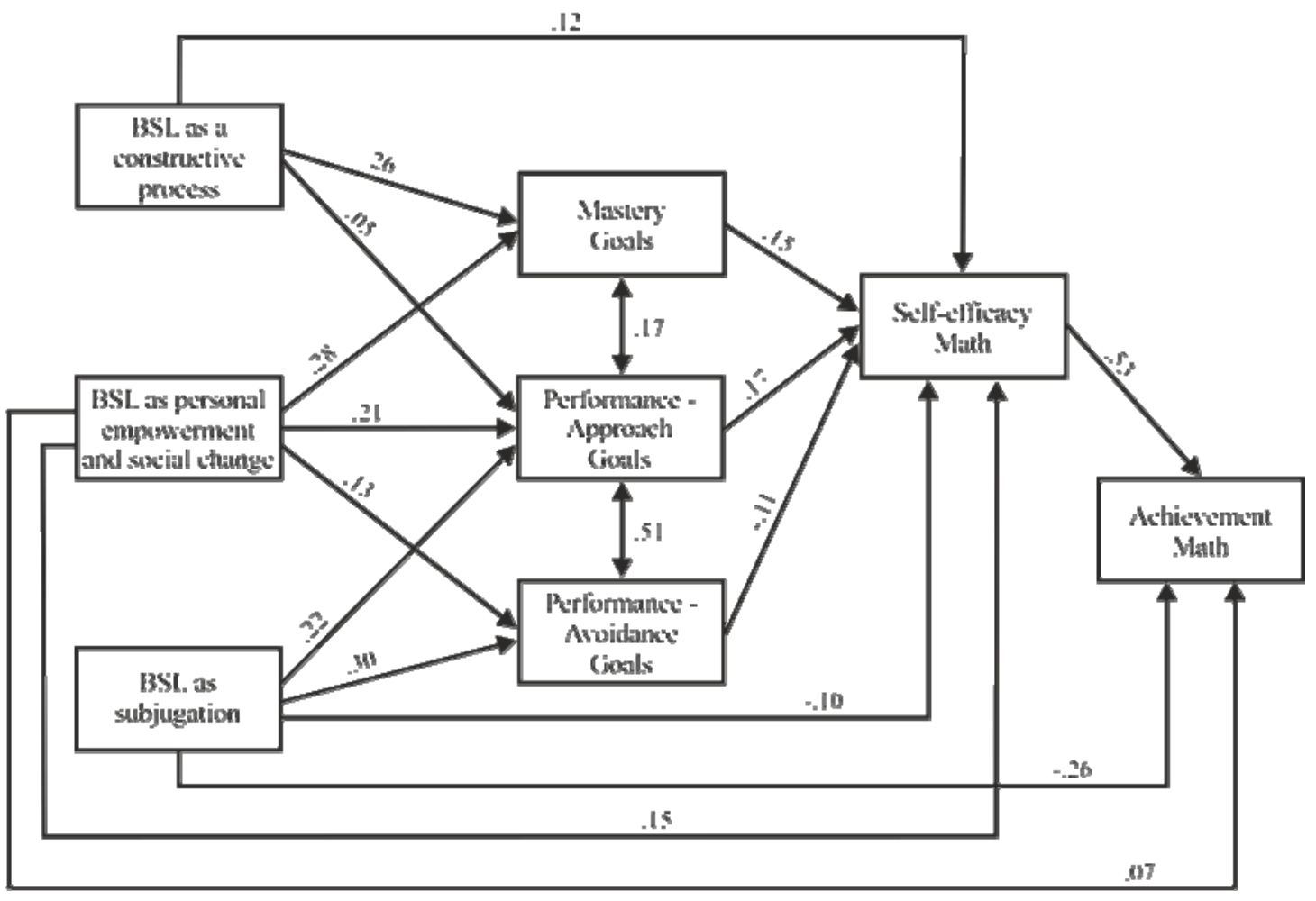

Figure 1. Standardized path coefficients for direct effects

Note. All path coefficients are significant $(p<.001)$. 


\section{Discussion}

The present study aimed at examining the direct and indirect effects of adolescents' beliefs about school learning (BSL) on: (a) student personal achievement goal orientations, (b) self-efficacy in mathematics, and (c) school achievement in mathematics. Contrary to most prior research, the present study focused on beliefs about school learning instead of focusing on knowledge and learning in general or on domain-specific beliefs related to mathematics. This particular choice was made in an attempt to feature the contribution of academic beliefs about learning (Muis et al., 2006) in addition to the well supported domain-specific epistemic beliefs (e.g., Chen \& Pajares, 2010; Tsai et al., 2011). Further, the study was carried out with adolescents; looking at adolescents is important both for theory and practice due to the extended cognitive and motivational changes that past research has well documented (e.g., Cano, 2005; Gonida et al., 2007; Pajares \& Valiante, 2002; Urdan \& Midgley, 2003). Moreover, adolescents have to take educational and occupational decisions about their future, whereas at the same time they are skeptical about the relevance and value of school learning for their future lives (e.g., Kenny, Walsh-Blair, Blustein, Bembechat, \& Seltzer, 2010; Kumar, Gheen, \& Kaplan, 2002).

\subsection{Beliefs about School Learning, Motivational Beliefs and Achievement}

The results of the present study confirmed most of our hypotheses and indicated direct effects of students' beliefs about school learning on achievement goal orientations, self-efficacy in mathematics and the respective achievement, as well as indirect effects on achievement via their significant paths to the motivational variables under examination. Moreover, indirect paths of BSL on academic self-efficacy via goal orientations as well as indirect paths of BSL and goal orientations on achievement via self-efficacy beliefs were also confirmed. Self-efficacy beliefs mediated the effect of students' beliefs about learning as well as the effect of personal achievement orientations on achievement. Further, BSL indirectly predicted academic self-efficacy in mathematics through their direct path on goal orientations. The above results clearly underline the importance of adopting a conception of school learning as a personal constructive process or as a force of personal empowerment and social change for the promotion of adaptive motivational patterns (i.e., mastery goal orientation and high efficacy beliefs) which, in turn, are more likely to increase school achievement. At the same time, beliefs about school learning as passively absorbed by the person and used as a means of subjugation of personal opinion to the opinions or actions of authorities directly predicted the adoption of performance goal orientations, both approach and avoidance, and low achievement in mathematics.

The above results, in addition to the well-established predictive value of domain-specific epistemic beliefs on students' academic motivation and achievement in different age samples and contexts (e.g., Chen \& Pajares, 2010; Tsai et al., 2011), indicate that beliefs about school learning independent of particular school subjects also play a significant role in student motivational beliefs and achievement even within specific subjects such as mathematics. As in the case of domain-specific epistemic beliefs as well as of the general epistemic beliefs, sophisticated and constructivist conceptions of school learning and knowledge are more likely to be associated with more adaptive motivational patterns and achievement outcomes as compared to naïve and reproductive conceptions (e.g., Chen \& Pajares, 2010; Muis \& Duffy, 2013; Peterson et al., 2010; Tsai et al., 2011). Further, the above results show an extended network of both direct and indirect relationships among BSL, achievement goal orientations and self-efficacy beliefs which significantly contributes to adolescents' school achievement.

However, it is noteworthy that two types of BSL did have a direct influence on achievement. Such results clearly emphasize, on the one hand, the beneficial contribution of BSL as a personal empowerment on achievement and, on the other hand, the detrimental role of theorizing school learning as subjugation. Apparently, when adolescents believe that schooling is a tool for personally meaningful growth which ultimately is related to social change and do not believe that schooling is a tool of impersonal authority resulting in preserving the social status quo, they are more likely to have adaptive motivational beliefs and higher academic achievement, especially in core school subjects such as mathematics, language or science. The above findings could be attributed at least to two reasons. First, they could be attributed to the great significance of school achievement and particularly of achievement in mathematics as a highly valued curriculum subject for future educational and occupational choices. Teachers and parents, through their achievement-related messages, communicate to adolescents the power of having high achievement for personal empowerment in regard to future consequences and eventually to social advancement. Second, the above findings could be also attributed to adolescents' idealism as well as to their skepticism about schooling. For those adolescents who believe in the power of school to bring positive changes in their personal lives as well as societal reforms, educational success is the way to do so. Those who are very skeptical about the role of school nowadays, that is they question its relevance and potential 
contribution to their future lives as well as to the society, are more vulnerable to develop a maladaptive motivational profile and, subsequently, low academic outcomes.

Interestingly, beliefs about school learning as personal empowerment and growth predicted both mastery and performance goal orientations. These beliefs do not necessarily lead only to the adoption of a mastery orientation in a context where achievement and school success are highly valued. Cultural influences have already been acknowledged in the literature of beliefs about learning or epistemological beliefs (e.g., Kuhn \& Park, 2005; Tabak \& Weistock, 2008). Kuhn and Park (2005) talk about cultural meaning systems which embed shared conceptions about the value of intellectual activities. The educational system in Greece, as in many other countries, is an achievement-oriented one. The pressure for achievement on students, especially on secondary school students, is very high resulting in a very competitive learning environment. Both family and school assign great value on having a high achievement trajectory at school which will eventually lead to the university. High achievement in secondary school as well as university entrance is considered, on the one hand, as a means for personal empowerment and growth and, on the other, as advancement of the society. In other words, personal empowerment in a very competitive learning context is likely to be associated to social comparison and, consequently, performance goals, including performance-avoidance goals, are also likely to be espoused. Within the epistemological beliefs research, the effect of sophisticated beliefs about knowledge and learning not only on mastery but also on performance goal orientations has been already evidenced in college students (Phan, 2009). Moreover, performance-approach goals are not necessarily maladaptive, as many studies have indicated. The evidence is still inconsistent depending upon a number of factors including the competitiveness of the context and the students' age (for this discussion, see Midgley, Kaplan, \& Middleton, 2001).

\subsection{Implications for Education}

The present study provided evidence for significant direct as well as indirect effects of beliefs about school learning on achievement-related motivational beliefs and achievement in mathematics during adolescence, a critical period for the development of students' belief system about schooling, school learning and knowledge, which hasn't been sufficiently studied yet (see Cano, 2005; Metallidou, 2012; Tsai et al., 2011). From an applied perspective, the results of the present study offer new insights to teachers and parents seeking to enhance adolescents' motivation for school learning and achievement. Teachers mostly elaborate on the content of the school subjects and only in best cases on the process, the goal and value of school learning for students' personal empowerment as well as for societal progress and reform. Unfortunately, they hardly elaborate on how knowledge is constructed, how students learn in meaningful ways and why it is important to learn. This seems to be insufficient in order for adolescents to value school learning and strive for competence through the development of an adaptive motivational profile which in turn would facilitate academic performance.

Three interesting findings of the present study could set the basis for future interventions: (a) the direct positive contribution of BSL as personal empowerment and meaningful growth to adolescents' motivational beliefs and achievement, (b) the direct positive contribution of the constructivist conception of school learning to the endorsement of mastery goals and to high self-efficacy beliefs, and (c) the direct negative contribution of the belief of school learning as subjugation and schooling as impersonal authority to achievement. Based on the above findings, secondary school teachers should provide adolescents with clear messages about the contructivistic character and the power of school learning, as well as they should assign greater value and encourage beliefs about it as means for personal empowerment and meaningful growth. By encouraging adolescents to refine their beliefs about school learning they may also facilitate them to alter possible dysfunctional beliefs about school knowing and learning and limit their skepticism about the value of school and school learning which is frequent among adolescents nowadays.

In their recent work, Muis and Duffy (2013) indicated the effectiveness of a classroom intervention designed to foster epistemic change in graduate students. Based on constructivistic teaching practices, the intervention was successful in changing students' epistemic beliefs, learning strategies, self-efficacy beliefs and achievement. In our opinion, adolescence also seems an appropriate period to work on students' beliefs about learning and knowing for a number of reasons. First, BSL are conceptually abstract (e.g., Schommer-Aikins et al., 2005), but adolescents do not have conceptual difficulties in understanding the constructive and evolving nature of knowing and learning. Second, adolescents have to take important educational and career decisions and beliefs about school learning do matter, especially those related to personal empowerment and change or those related to subjugation. Moreover, adolescents' critical approach of the society (Elkind, 1985) should be associated with the potential contribution of schooling to societal changes. 
Furthermore, the issue of teachers', parents' and caregivers' beliefs about school learning and their subsequent instructional practices rises, as well. The promotion of students' adaptive beliefs about school learning in the school or the family context presupposes that teachers and parents share advanced conceptions of school learning such as learning as a personal constructive process or as a force of personal empowerment and social change and create appropriate learning environments. This is not self-evident (see, for example, Gill, Ashton, \& Algina, 2004; Sinatra \& Kardash, 2004; Tsai, 2002); future studies and potential intervention programs should take into account this aspect.

\subsection{Limitations and Future Research}

A number of limitations could be addressed in future research. Firstly, the correlational nature of the data suggests that causality should not be assumed. Secondly, the study relied on data gathered concurrently at a single time point in a particular context. Longitudinal studies that follow beliefs about school learning as students move from grade to grade or from one educational level to another would allow us to better describe the changes that might occur in the variables under examination and clarify the associations among them. Third, Likert-type scales were used to measure most of the study variables. Although Likert scales have been predominant in motivation research, they have been criticized for their risks to result in imprecise findings mainly due to the problematic assumption that they provide interval-level measurement. Multi-method approaches using self-reports and behavioural measures should be encouraged in future motivational studies (for a detailed discussion, see Fulmer \& Frijters, 2009). Fourth, despite the availability of a very large pool of data and the good reliability values of the three scales measuring the beliefs about school learning, the instrument used in the present study should be replicated in future studies with samples coming from different social and educational contexts where school learning is valued differently. Finally, the co-examination of beliefs about school learning with domain-specific epistemic beliefs would further strengthen our knowledge about the unique contribution of each type of epistemic beliefs as well as about the association between them.

\section{Acknowledgements}

This study was part of a broader research project funded by the European Social Fund and the Hellenic Ministry of Education and Religious Affairs (Operational programme for Education and Initial Vocational Training, within the Third Community Support Framework). We thank the co-ordinator of the project Prof. Vassiliki Deliyiannis-Kouimtzis, Prof. Grigoris Kiosseoglou for his statistical advice, and all our collaborators for their contribution in data collection. We would also like to express our deepest thanks to Dr. Barbara Greene who provided us with the permission to use the Beliefs about School Learning Questionnaire and for her insightful comments and suggestions on an earlier draft of this work.

\section{References}

Bandura, A. (1986). Social foundations of thought and action: A social cognitive theory. Englewood Cliffs, NJ: Prentice Hall.

Bandura, A. (1997). Self-efficacy: The exercise of control. New York: Freeman.

Bråten, I., \& Strømsø, H. I. (2004). Epistemological beliefs and implicit theories of intelligence as predictors of achievement goals. Contemporary Educational Psychology, 29, 371-388. http://dx.doi.org/10.1016/j.cedpsych.2003.10.001

Bråten, I., \& Strømsø, H. I. (2005). The relationship between epistemological beliefs, implicit theories of intelligence, and self-regulated learning among Norwegian postsecondary students. British Journal of Educational Psychology, 75, 539-565. http://dx.doi.org/10.1348/000709905X25067

Cano, F. (2005). Epistemological beliefs and approaches to learning: Their change through secondary school and their influence on academic performance. British Journal of Educational Psychology, 75, 203-221. http://dx.doi.org/10.1348/000709904X22683

Cano, F., \& Cardelle-Elawar, M. (2004). An integrated analysis of secondary school students' conceptions and beliefs about learning. European Journal of Psychology of Education, 19, 167-187. http://dx.doi.org/10.1007/ BF03173230

Chan, C. K. K., \& Sachs, J. (2001). Children's beliefs about learning and understanding of science texts. Contemporary Educational Psychology, 26, 192-210. http://dx.doi.org/10.1006/ceps.1999.1045 
Chen, J. A., \& Pajares, F. (2010). Implicit theories of ability of grade 6 science students: Relation to epistemological beliefs and academic motivation and achievement in science. Contemporary Educational Psychology, 35, 75-87. http://dx.doi.org/10.1016/j.cedpsych.2009.10.003

Church, M. A., Elliot, A. J., \& Gable, S. L. (2001). Perceptions of classroom environment, achievement goals, and achievement outcomes. Journal of Educational Psychology, 93, 43-54. http://dx.doi.org/10.1037/ 0022-0663.93.1.43

Cohen, J. (1988). Statistical power analysis of the behavioral science. New York: Academic Press.

DeBacker, T. K., \& Crowson, H. M. (2006). Influences on cognitive engagement: Epistemological beliefs and need for closure. British Journal of Educational Psychology, 76, 535-551. http://dx.doi.org/ $10.1348 / 000709905 \times 53138$

Eccles, J., \& Midgley, C. (1989). Stage/environment fit: Developmentally appropriate classrooms for early adolescents. In R. E. Ames, \& C. Ames (Eds.), Research on motivation in education (Vol. 3, pp. 139-186). New York: Academic Press.

Elkind, D. (1985). Egocentrism redux. Developmental Review, 5, 218-226. http://dx.doi.org/10.1016/ 0273-2297(85)90010-3

Elliot, A. J. (2005). A conceptual history of the achievement goal construct. In A. J. Elliot, \& C. S. Dweck (Eds.), Handbook of competence and motivation (pp. 52-72). New York: The Guliford Press.

Elliot, A. J., \& Harackiewicz, J. M. (1996). Approach and avoidance achievement goals and intrinsic motivation: A mediational analysis. Journal of Personality and Social Psychology, 70, 461-475. http://dx.doi.org/10.1037/0022-3514.70.3.461

Fan, X., \& Sivo, S. A. (2007). Sensitivity of fit indexes to miss specified structural or measurement model components: Rationale of two-index strategy revisited. Structural Equation Modeling, 12, 343-367. http://dx.doi.org/10.1207/s15328007sem1203_1

Friedel, J., Cortina, K. S., Turner, J. C., \& Midgley, C. (2007). Achievement goals, efficacy beliefs and coping strategies in mathematics: The roles of perceived parent and teacher goal emphases. Contemporary Educational Psychology, 32, 434-458. http://dx.doi.org/10.1016/j.cedpsych.2006.10.009

Fulmer, S. M., \& Frijters, J. C. (2009). A review of self-report and alternative approaches in the measurement of student motivation. Educational Psychology Review, 21, 219-246. http://dx.doi.org/10.1007/s10648-009-9107-x

Gill, M. G., Ashton, P. T., \& Algina, J. (2004). Changing preservice teachers' epistemological beliefs about teaching and learning in mathematics: An intervention study. Contemporary Educational Psychology, 29, 164-185. http://dx.doi.org/10.1016/j.cedpsych.2004.01.003

Gonida, E. N., Kiosseoglou, G., \& Voulala, K. (2007). Perceptions of parents goals and their contribution to student achievement goal orientations and engagement in the classroom: Grade-level differences across adolescence. European Journal of Psychology of Education, 22, 23-39. http://dx.doi.org/10.1007/ BF03173687

Gonida, E. N., \& Leondari, A. (2011). Patterns of motivation among adolescents with biased and accurate self-efficacy beliefs. International Journal of Educational Research, 50, 209-220. http://dx.doi.org/10.1016/j.jijer.2011.08.002

Gonida, E. N., Voulala, K., \& Kiosseoglou, G. (2009). Students' achievement goal orientations and their behavioral and emotional engagement: Co-examining the role of perceived school goal structures and parent goals during adolescence. Learning and Individual Differences, 19, 53-60. http://dx.doi.org/10.1016/j.lindif.2008.04.002

Greene, B. A., Miller, R. B., Crowson, H. M., Duke, B. L., \& Akey, K. L. (2004). Predicting high school students' cognitive engagement and achievement: Contributions of classroom perceptions and motivation. Contemporary Educational Psychology, 2, 462-482. http://dx.doi.org/10.1016/j.cedpsych.2004.01.006

Hofer, B. K. (2001). Personal epistemology research: Implications for learning and teaching. Journal of Educational Psychology Review, 13, 353-383. http://dx.doi.org/10.1023/A:1011965830686 
Hofer, B. K., \& Pintrich, P. R. (1997). The development of epistemological theories: Beliefs about knowledge and knowing and their relation to learning. Review of Educational Research, 67, 88-140. http://dx.doi.org/10.3102/00346543067001088

Hu, L.-T., \& Bentler, P. M. (1999). Cut-off criteria for fit indexes in covariance structure analysis: Conventional criteria versus new alternatives. Structural Equation Modeling, 6, 1-55. http://dx.doi.org/10.1080/10705519909540118

Kenny, M. E., Walsh-Blair, L. Y., Blustein, D. L., Bembechat, J., \& Seltzer, J. (2010). Achievement motivation among urban adolescents: Work hope, autonomy support, and achievement-related beliefs. Journal of Vocational Behavior, 77, 205-212. http://dx.doi.org/10.1016/j.jvb.2010.02.005

Kline, R. B. (2011). Principles and practice of structural equation modeling (3rd ed.). New York: Guilford Press.

Kuhn, D., \& Park, S. (2005). Epistemological understanding and the development of intellectual values. International Journal of Educational Research, 43, 111-124. http://dx.doi.org/10.1016/j.ijer.2006.05.003

Kumar, R., Gheen, M. H., \& Kaplan, A. (2002). Goal structures in the learning environment and students' disaffection from learning and schooling. In C. Midgley (Ed.), Goals, goal structures, and patterns of adaptive learning (pp. 143-173). Mahwah, NJ: Erlbaum.

Law, Y.-K., Chan, C. K. K., \& Sachs, J. (2008). Beliefs about learning, self-regulated strategies and text comprehension among Chinese children. British Journal of Educational Psychology, 78, 51-73. http://dx.doi.org/ 10.1348/000709907X179812

Mansell, R. A., Greene, B. A., \& DeBacker, T. K. (2004, September). Searching for meaning: Epistemological beliefs and their relationships with motivation to learn. Paper presented at the International Conference on Motivation: "Cognition, Motivation, and Affect", Lisbon, Portugal.

Marton, F., Dall'Alba, G., \& Beaty, E. (1993). Conceptions of learning. International Journal of Educational Research, 19, 277-300.

Metallidou, P. (2012). Epistemological beliefs as predictors of self-regulated learning strategies in middle school students. School Psychology International, 34, 283-298. http://dx.doi.org/10.1177/0143034312455857

Metallidou, P., Megari, K., \& Konstantinopoulou, E. (2010). Epistemological beliefs as predictors of personal achievement goals of high school students. Psychology: The Journal of Hellenic Psychological Society, 17, 382-403.

Metallidou, P., \& Vlachou, A. (2007). Motivational beliefs, cognitive engagement, and achievement in Language and Mathematics in elementary school children. International Journal of Psychology, 42, 2-15. http://dx.doi.org/ 10.1080/00207590500411179

Middleton, M. J., \& Midgley, C. (1997). Avoiding the demonstration of lack of ability: An under-explored aspect of goal theory. Journal of Educational Psychology, 89, 710-718. http://dx.doi.org/10.1037/0022-0663. 89.4.710

Midgley, C. (Ed.). (2002). Goals, goal structures, and patterns of adaptive learning. Mahwah, NJ: Erlbaum.

Midgley, C., Kaplan, A., \& Middleton, M. (2001). Performance-approach goals: Good for what, for whom, under what circumstances, and at what cost? Journal of Educational Psychology, 93, 77-86. http://dx.doi.org/ 10.1037/0022-0663.93.1.77

Midgley, C., Kaplan, A., Middleton, M., Maehr, M. L., Urdan, T., ... Hicks, L. H. (1998). The development and validation of scales assessing students' achievement goal orientations. Contemporary Educational Psychology, 23, 113-131. http://dx.doi.org/10.1006/ceps.1998.0965

Muis, R. K. (2008). Epistemic profiles and self-regulated learning: Examining relations in the context of mathematics problem solving. Contemporary Educational Psychology, 33, 177-208. http://dx.doi.org/ 10.1016/j.cedpsych.2006.10.012

Muis, R. K., \& Duffy, M. C. (2013). Epistemic climate and epistemic change: Instruction designed to change students' beliefs and learning strategies and improve achievement. Journal of Educational Psychology, 105, 213-225. http://dx.doi.org/10.1037/a0029690 
Muis, R. K., Bendixen, L. D., \& Haerle, F. C. (2008). Domain-generality and domain-specificity in personal epistemology research: Philosophical and empirical reflections in the development of a theoretical framework. Educational Psychology Review, 18, 3-54. http://dx.doi.org/10.1007/s10648-006-9003-6

Muis, K. R., \& Franco, G. M. (2009). Epistemic beliefs: Setting the standards for self-regulated learning. Contemporary Educational Psychology, 34, 306-318. http://dx.doi.org/10.1016/j.cedpsych.2009.06.005

Muthén, L. K., \& Muthén, B. O. (2007). Mplus Users' guide: Statistical analysis with latent variables (5th ed.). Los Angeles, CA: Muthén \& Muthén.

Pajares, F., \& Schunk, D. H. (2001). Self-beliefs and school success: Self-efficacy, self-concept, and school achievement. In R. Riding, \& S. Rayner (Eds.), Self-perception (pp. 239-266). London: Ablex Publishing.

Pajares, F., \& Valiante, G. (2002). Student's self-efficacy in their self-regulated learning strategies: A developmental perspective. Psychologia: An International Journal of Psychology in the Orient, 45, 211-221. http://dx.doi.org/10.2117/psysoc.2002.211

Peterson, E. R., Brown, G. T. L., \& Irving, S. E. (2010). Secondary school students' conceptions of learning and their relationship to achievement. Learning and Individual Differences, 20, 167-176. http://dx.doi.org/ 10.1016/ j.lindif.2009.12.004

Phan, H. P. (2009). Amalgamation of future time orientation, epistemological beliefs, achievement goals and study strategies: Empirical evidence established. British Journal of Educational Psychology, 79, 155-173. http://dx.doi.org/10.1348/000709908X306864

Purdie, N., \& Hattie, J. (2002). Assessing students' conceptions of learning. Australian Journal of Educational \& Developmental Psychology, 2, 17-32.

Säljö, R. (1979). Learning in the learner's perspective: Some common-sense conceptions. Gothenburg: University of Gothenburg, Department of Education (Rep. No.76).

Sanders-Reio, J., Alexander, P. A., Reio, T. G., \& Newman, I. (2014). Do students' beliefs about writing relate to their writing self-efficacy, apprehension, and performance? Learning and Instruction, 33, 1-11. http://dx.doi.org/10.1016/j.learninstruc.2014.02.001

Schommer, M. (1990). Effects of beliefs about the nature of knowledge on comprehension. Journal of Educational Psychology, 82, 498-504. http://dx.doi.org/10.1037/0022-0663.89.1.37

Schommer-Aikins, M. (2002). An evolving theoretical framework for an epistemological belief system. In B. K. Hofer, \& P. R. Pintrich (Eds.), Personal epistemology: The psychology of beliefs about knowledge and knowing (pp. 103-118). Mahwah, NJ: Lawrence Erlbaum.

Schommer, M., Calvert, C., Gariglietti., G., \& Bajaj, A. (1997). The development of epistemological beliefs among secondary students: A longitudinal study. Journal of Educational Psychology, 89, 37-40. http://dx.doi.org/10.1037/0022-0663.89.1.37

Schommer-Aikins, M., Duell, O. K., \& Hutter, R. (2005). Epistemological beliefs, mathematical problem-solving beliefs, and academic performance of middle school students. The Elementary School Journal, 105, 289-304. http://dx.doi.org/10.1086/428745

Sinatra, G. M., \& Kardash, C. M. (2004). Teacher candidates' epistemological beliefs, dispositions, and views on teaching as persuasion. Contemporary Educational Psychology, 29, 483-498. http://dx.doi.org/10.1016/j.cedpsych.2004.03.001

Tabak, I., \& Weinstock, M. (2008). A sociocultural exploration of epistemological beliefs. In M. S. Khine (Ed.), Knowing, Knowledge and beliefs: Epistemological Studies across Diverse Cultures (pp. 177-195). New York: Springer. http://dx.doi.org/10.1007/978-1-4020-6596-5

Tsai, C.-C. (2002). Nested epistemologies: Science teachers' beliefs of teaching, learning and science. International Journal of Science Education, 24, 771-783. http://dx.doi.org/10.1080/09500690110049132

Tsai, C.-C., Ho, H. N. J., Liang, J.-C., \& Lin, H.-M. (2011). Scientific epistemic beliefs, conceptions of learning science and self-efficacy of learning science among high school students. Learning and Instruction, 21, 757-769. http://dx.doi.org/10.1016/j.learninstruc.2011.05.002 
Tuominen-Soini, H., Salmela-Aro, K., \& Niemivirta, M. (2012). Achievement goal orientations and achievement well-being across the transition to upper secondary education. Learning \& Individual Differences, 22, 290-305. http://dx.doi.org/10.1016/j.lindif.2012.01.002

Tynjälä, P. (1997). Developing education students' conceptions of the learning process in different learning environments. Learning and Instruction, 7, 277-292. http://dx.doi.org/10.1016/S0959-4752(96)00029-1

Urdan, T., \& Midgley, C. (2003). Changes in the perceived classroom goal structure and pattern of adaptive learning during early adolescence. Contemporary Educational Psychology, 28, 524-551. http://dx.doi.org/ $10.1016 / \mathrm{S} 0361-476 \mathrm{X}(02) 00060-7$

\section{Copyrights}

Copyright for this article is retained by the author(s), with first publication rights granted to the journal.

This is an open-access article distributed under the terms and conditions of the Creative Commons Attribution license (http://creativecommons.org/licenses/by/3.0/). 